\title{
A NEW SPECIES OF ALLOGALUMNA \\ (ACARI, ORIBATIDA, GALUMNIDAE) FROM IRAN, INCLUDING A KEY TO ALL SPECIES OF THE GENUS
}

\author{
Mohammad Ali Akrami \\ Department of Plant Protection, College of Agriculture, Shiraz University, Shiraz, Iran \\ E-mail:akrami@shirazu.ac.ir
}

\begin{abstract}
A new oribatid mite species of the family Galumnidae, Allogalumna (Allogalumna) iranica sp. n., is described from Iranian soil. It is characterized by the rounded rostrum; long, slightly thick and barbulate interlamellar setae; medium long, thin and smooth rostral and lamellar setae; long sensilli, with densely barbed, slightly dilated lanceolate head; dorsosejugal furrow medially undeveloped; presence of median pore in females and males; large, nearly oval porose areas $A a$; and large, elongated, medially narrowed postanal porose area and tridactylous legs. An identification key for the known species of Allogalumna is presented.
\end{abstract}

Key words: Acari, Galumnidae, Allogalumna, new species, Iran, key.

\section{INTRODUCTION}

Oribatid mites (Acari: Oribatida) of the family Galumnidae is one of the largest groups of mites with a world-wide distribution, and it comprises 34 genera with about 470 species (SubíAs 2014). There is little information on this family in Iran and a few species have been recorded (Mahunka \& AKrami 2001, Акrami 2007, Акrami et al. 2011, Вауавтоgтокн \& Акrami 2014). In the course of a study on oribatid mites of pastures in Fars province, southern Iran, one new species belonging to this family was found. Here, I describe one new species of the genus Allogalumna and present an identification key to all known species of the genus. Prior to this study there was only one record of this genus from Iran (BAYARTOGTOKH \& AKRAMi 2014).

The genus Allogalumna was established by Grandjean (1936) with $\mathrm{Ga}$ lumna alamellae Jacot, 1935 as the type species. Currently, this genus has two subgenera: Allogalumna, with anal lyrifissures close to anal plates and Globogalumna, with anal lyrifissures removed from anal plates (ERmilov \& ANichKin 2014). The diagnostic characters of the genus were summarized by ErmiLov et al. (2013).

\section{MATERIAL AND METHODS}

Soil samples were taken from various pastures at Shiraz township, Fars province. Mites were extracted from samples in Berlese-Tullgren funnels set over jars with $75 \%$ etha- 
nol. Mites were removed, cleared in lactophenol and mounted in Hoyer's medium on glass microscopic slides. The slides were placed in an oven at $45^{\circ} \mathrm{C}$ for two weeks. One specimen was mounted in lactic acid on a temporary cavity slide for measurement and illustration. Mites were studied using a light microscope (Zeiss Standard 20). Figures were made using a drawing tube attached to the microscope. Body length was measured from the tip of the rostrum to the posterior edge of the notogaster, and body width refers to the maximum width of the notogaster in dorsal aspect. The length variation of some body setae is given in parenthesis. All body measurements are presented in micrometers $(\mu \mathrm{m})$. The holotype and paratypes are deposited in the Acarological Collection of the Department of Plant Protection, Faculty of Agriculture, Shiraz University, Iran. General terminology used in this paper follows that of Norton and Behan-Pelletier (2009).

\section{DESCRIPTION OF THE NEW SPECIES Allogalumna (Allogalumna) iranica sp. $n$.}

(Figs 1-14)

Diagnosis - Allogalumna (Allogalumna) iranica sp. n. is characterized by the combination of the following character states: Body size 453-489 $\times 350$ 380; rostrum rounded; rostral and lamellar setae medium long, thin and smooth; interlamellar setae long and thick, finely barbed; sensilli long, with densely barbed, slightly dilated lanceolate head; dorsosejugal furrow medially not developed; four pairs of round porose areas, $A a$ larger, slightly oval; postanal porose area elongated, narrowed medially; dorsal median pore present in females and males.

Material examined - Holotype (female): Ghalat, Fars Province, southern Iran, soil of pasture under Centaurea sp. and Hordeum sp. (Gramineae), 29 $48^{\prime} \mathrm{N}$; 52 $2^{\circ} 19^{\prime} \mathrm{E}, 2070 \mathrm{~m}$ a.s.l., 16.x.2012, F. Ebrahimi leg.; four paratypes (two females, two males): same data as holotype.

Description - Integument. Body color yellowish-brown. Cerotegument with small granules. Cuticle of body in dorsolateral parts of notogaster with radiate impressions. Pteromorphs with fine striations.

Measurements. Holotype: body length 500, width of notogaster 395, length of notogaster 368; paratypes $(n=4)$ : body length 453, 489 (females); 453, 474 (males); width of notogaster 350-380, length of notogaster 368-380. Males and females similar in size.

Prodorsum (Figs 1, 4, 5-7). Rostrum rounded. Sublamellar line distinct. Rostral setae $(r o, 49-56)$ thin, setiform, smooth, inserted ventro-laterally and well visible in dorsofrontal view. Lamellar setae (le, 46-53) thin, smooth. Interlamellar setae (in, 72-81) long, thickened, finely barbed bilaterally, not reaching the tip of rostrum. Exobothridial setae not observed. Sensilli (ss, 103-125) with long and narrow stalk and densely barbed, slightly dilated lanceolate head. A pair of elongate oval adalar porose areas Ad located posterior to interlamellar setae.

Notogaster (Figs 1, 10, 11). Notogaster widely rounded posteriorly. Dorsosejugal furrow not developed medially (between dorsophragmata). Pteromorphs with fine striations. Notogastral setae vestigial, their alveoli discernable. Four pairs of porose areas present: $A a$ 
$(26 \times 20)$ large, nearly oval, $A_{1}(18 \times 17), A_{2}(18 \times 13)$ and $A_{3}(17 \times 13)$ nearly rounded. Median pore present in both sexes, situated in middle line between porose areas $A_{2}$. Opisthonotal gland openings ( $\mathrm{gla}$ ) situated anterolaterad of $A_{1}$. Lyrifissures im inserted anteromedially to $A_{1}$, rather far from it, in front of setae $l p$.

Gnathosoma (Figs 13, 14). Subcapitulum bearing three pairs of hypostomal setae, all thin and densely barbed. Palp typical for family, all setae except on tarsus finely barbed, formula of setation: 0-2-1-3-9 (+1 $\omega)$, solenidion $\omega$ and eupathidium $\mathrm{acm}$ on tarsus fused and three other eupathidia not fused and located far to each other. Chelicera with sclerotized teeth, cheliceral setae setiform, barbed, cha longer than chb.
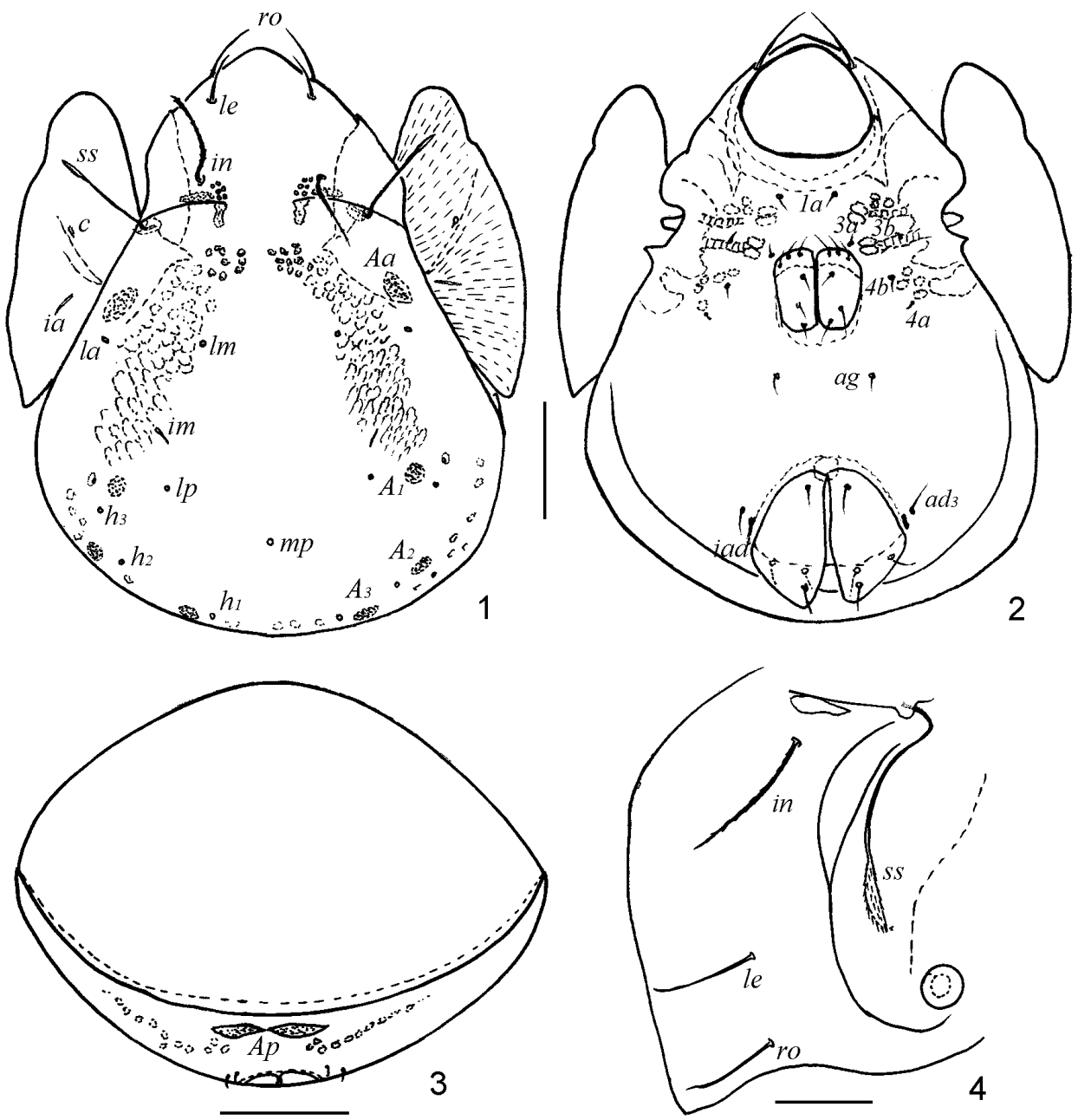

Figs 1-4. Allogalumna (Allogalumna) iranica sp. n.: $1=$ dorsal view; $2=$ ventral view, gnathosoma and legs not shown; $3=$ posterior view; $4=$ lateral view of prodorsum. Scale bars: $1-3=100 \mu \mathrm{m}, 4=50 \mu \mathrm{m}$. 
Epimeral region (Fig. 2). Apodemes apo.1, apo.2, apo.sj and apo.3 well developed. Only five pairs of short epimeral setae observed, setal formula: 1-0-2-2.

Anogenital region (Figs 2, 3, 8, 9). Anal and genital apertures situated far from each other, anal aperture $(112 \times 118)$ much larger than genital aperture $(66 \times 80)$. Six pairs of genital setae (13-19), three arranged on anterior edge, one inserted in middle part and two others

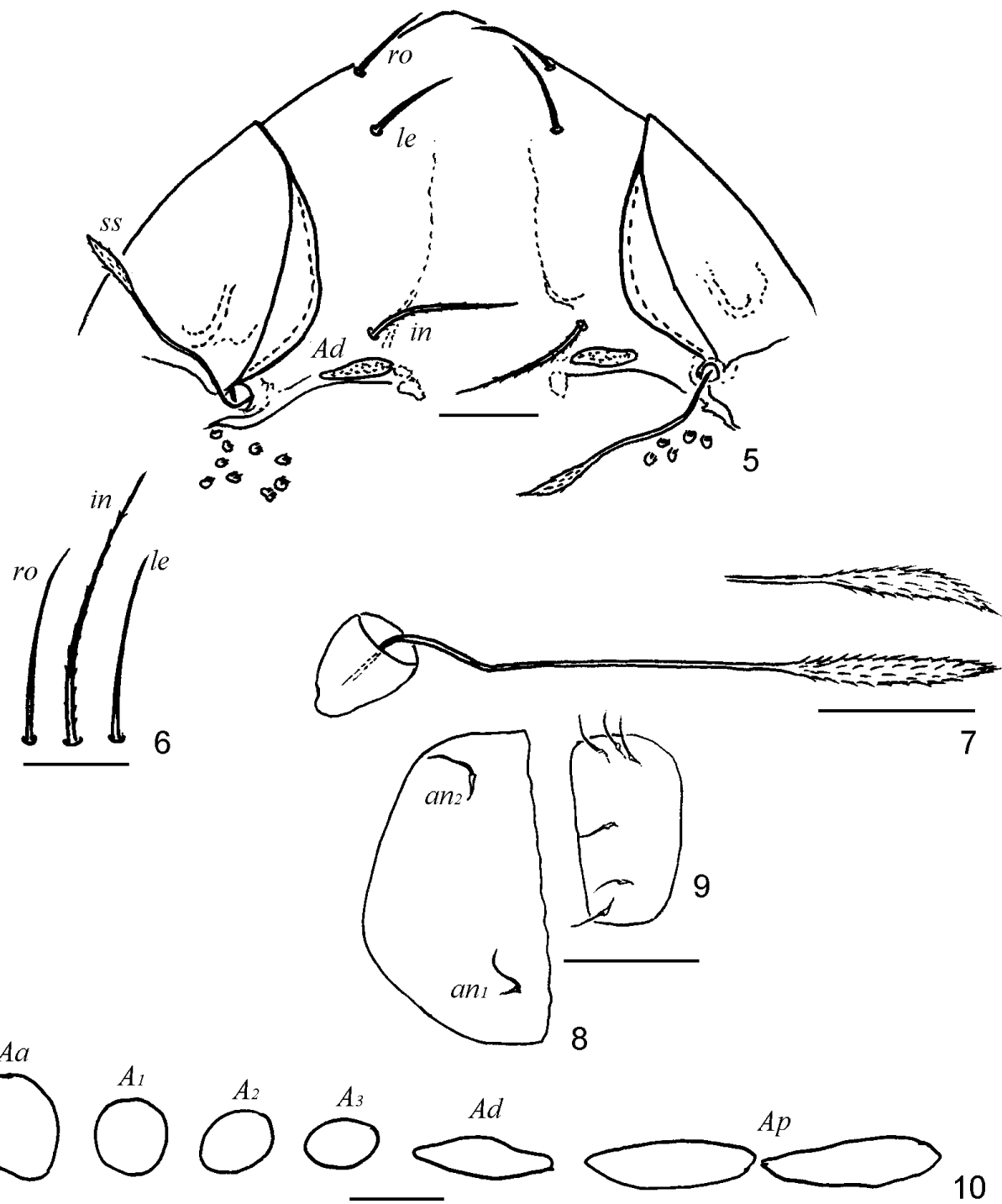

Figs 5-10. Allogalumna (Allogalumna) iranica sp. n.: $5=$ dorso-anterior view of prodorsum; $6=\operatorname{rostral}(r o)$, interlamellar (in) and lamellar (le) setae; $7=$ sensillus; $8=$ anal plate, right; $9=$ genital plate, left; $10=$ notogastral $\left(A a, A_{1}-A_{3}\right)$, adalar $(A d)$ and postanal $(A p)$ porose areas. Scale bars: $5,8,9=50 \mu \mathrm{m}, 6,7,10=25 \mu \mathrm{m}$. 
on posterior half of genital plates. One pair of aggenital setae (13) situated posterior to genital aperture. Two pairs of anal (20-22) and three pairs of adanal setae (22-26). Adanal lyrifissures iad situated in paranal position, slightly posterior to setae $a d_{3}$. All anogenital setae short and smooth. A large, elongated postanal porose area Ap present, narrowed medially.

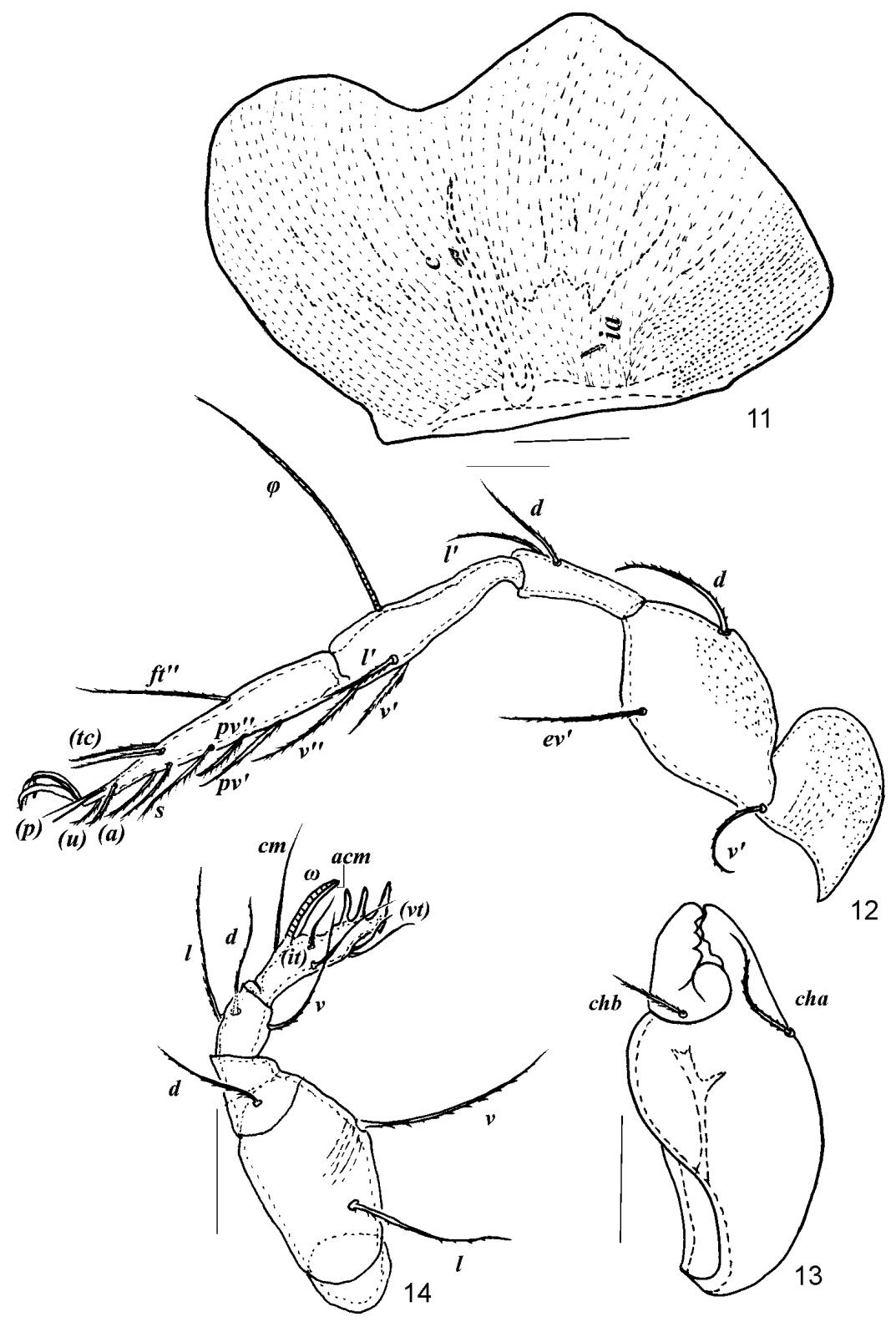

Figs 11-14. Allogalumna (Allogalumna) iranica sp. n.: $11=$ pteromorph; $12=$ leg IV (right, antiaxial view); 13 = chelicera; $14=$ palp. Scale bars: $11-13=50 \mu \mathrm{m}, 14=25 \mu \mathrm{m}$. 
Table 1. Leg setation and solenidia of adult Allogalumna (Allogalumna) iranica sp. $\mathrm{n}$.

\begin{tabular}{cccccc}
\hline Leg* & Trochanter & Femur & Genu & Tibia & Tarsus \\
\hline I & $v^{\prime}$ & $d,(l), b v^{\prime \prime}$ & $(l), v^{\prime}, \sigma$ & $(l),(v), \phi_{1^{\prime}} \phi_{2}$ & $(f t),(t c),(i t),(p),(u),(a), s,(p v)$, \\
& & & & $(p l), l^{\prime \prime}, \varepsilon, \omega_{1^{\prime}} \omega_{2}$ \\
II & $v^{\prime}$ & $d,(l), b v^{\prime \prime}$ & $(l), v^{\prime}, \sigma$ & $(l),(v), \phi$ & $(f t),(t c),(i t),(p),(u),(a), s,(p v)$, \\
& & & & & $\omega_{1^{\prime}} \omega_{2}$ \\
III & $v^{\prime}$ & $d, e v^{\prime}$ & $l^{\prime}, \sigma$ & $l^{\prime},(v), \phi$ & $(f t),(t c),(i t),(p),(u),(a), s,(p v)$ \\
IV & $v^{\prime}$ & $d, e v^{\prime}$ & $d, l^{\prime}$ & $l^{\prime},(v), \phi$ & $f t^{\prime \prime},(t c),(p),(u),(a), s,(p v)$ \\
\hline
\end{tabular}

* In leg formulae, Roman letters refer to normal setae, Greek letters to famulus and solenidia. Single prime (') marks setae on anterior and double prime (") setae on posterior side of the given leg segment and parentheses refer to a pair of setae.

Legs (Fig. 12). All legs tridactylous with stronger median and slender lateral claws. Structure and setation of legs typical for family. All setae on podomeres barbed, especially some ventral setae of tarsi heavily barbed with long cilia. Formula of setation, including famulus: I (1-4-3-4-20), II (1-4-3-4-15), III (1-2-1-3-15), IV (1-2-2-3-12), formula of solenidia I (1-2-2), II (1-1-2), III (1-1-0), IV (0-1-0). Homology of setae and solenidia indicated in Table 1.

Etymology - The specific name "iranica" refers to the type locality of this species, Iran.

Remarks - Allogalumna (Allogalumna) iranica sp. $\mathrm{n}$. is unique among the known species of Allogalumna by the combination of the following features, namely the undeveloped medial portion of the dorsosejugal furrow; four pairs of round or nearly oval porose areas; slightly dilated lanceolate head of sensilli with long stalk; the rounded rostrum; the long, thickened interlamellar setae, position of lyrifissures im anteromediad of $A_{1}$, presence of notogastral median pore (in females and males) and a large, elongated postanal porose area.

The European species, A. (A.) integer described by Berlese (1904) as Oribata alata integer and redescribed by MaHUNKa (1992) resembles the new species in the structure of porose areas, dilated sensilli, long interlamellar setae and undeveloped medial portion of the dorsosejugal furrow. However, the former species is distinguished from the present new species by the shorter stalk and swollen head of sensilli; longer and barbulate lamellar setae; insertion of lyrifissures im laterad of porose areas $A_{1}$; insertion of notogastral median pore posteromediad of porose areas $A_{2} ;$ smaller adalar and notogastral porose areas, and different position of notogastral setae $c$ on pteromorphs.

The Mediterranean species, A. (A.) parva described by Berlese (1916) as Oribata parous and redescribed by MaHUnKA (1992) is similar to Allogalumna (A.) iranica sp. $\mathrm{n}$. in the structure of porose areas and prodorsal setae, but it is different from the new species in the shorter sensilli, with clavate head; 
absence of dorsosejugal furrow; insertion of lyrifissures $\mathrm{im}$ laterad of porose areas $A_{1}$, and smaller body size $(420 \times 320)$.

The Turkish species, A. (A.) turkeyensis described by Grobler et al. (2004) resembles the new species in slightly dilated sensilli. However, the former species is distinguishable from the new species by the shorter sensilli with rounded tip; thicker interlamellar setae; longer lamellar setae; larger porose areas $A_{1}, A_{2}$ and $A_{3}$; insertion of lyrifissures im laterad of porose areas $A_{1}$, and smaller body size $(369-421 \times 220-242)$.

\section{DISCUSSION}

Currently, the genus Allogalumna comprises more than 40 species having a cosmopolitan distribution collectively (AOKI \& Hu 1993, ERMiLOv \& ANICHKin 2012, 2014, Bayartogtoкh \& Aкrami 2014, Ermilov \& Kalúz 2014, ErMiLov et al. 2014, Subías 2014). There are some features such as presence or absence of dorsosejugal furrow; number and shape of porose areas especially $A a$; shape of sensilli; presence or absence and size of rostral, lamellar and interlamellar setae; presence or absence of notogastral median pore (in females and males); position of lyrifissures im and number of claws (one or three) that differentiate the species in this genus. In conclusion, the following key (including 41 species until now) can be used to identify adults of all known species of Allogalumna. The measurements and distribution of all species is given in parentheses.

\section{A KEY TO THE KNOWN SPECIES \\ OF ALLOGALUMNA GRANDJEAN, 1936}

(Figs 15-56)

1 Adanal lyrifissures (iad) removed from anal plates [subgenus Globogalumna]

- Adanal lyrifissures (iad) located very close to anal plates [subgenus Allogalumna]

2 Notogaster with only two pairs of porose areas; prodorsum without a transverse line anteriorly to interlamellar setae; notogastral cerotegument with ornamentation $(250 \times 159-164)$

A. (G.) biporosa Ermilov et Anichkin, 2012 (Vietnam)

- Four pairs of porose areas; prodorsum with a transverse line anteriorly to interlamellar setae; notogaster smooth, without ornamentation (236$244 \times 168-176) \quad$ A. (G.) globulifera (Balogh et Mahunka, 1978) (Brazil) 

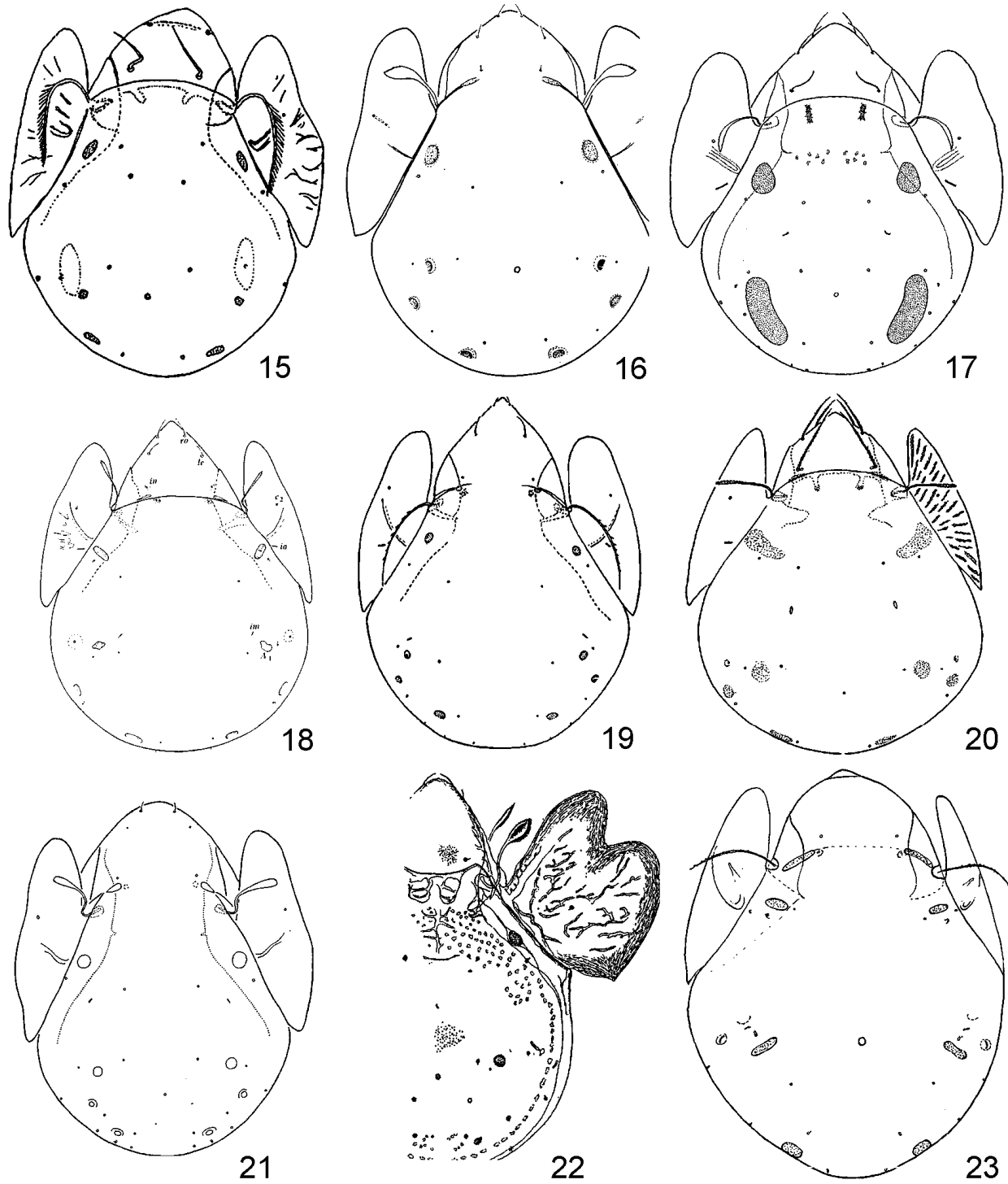

Figs 15-23. Allogalumna species: 15 = Allogalumna (A.) alpha (after Pérez-Íñ̃go \& BAggio 1994); $16=$ A. (A.) borhidii (after Balogh \& MahunKa 1979); $17=$ A. (A.) confluens (after BALOGH 1960a); $18=$ A. (A.) antillensis (after MAHUnKA 1998); $19=$ A. (A.) costata (after MAHUNKA 1996); $20=$ A. (A.) dentirostrata (after Bayartogtoкh \& Акrami 2014); $21=A$. (A.) dilatata (after Balogh \& Balogh 1983); 22 = A. (A.) exigua (after Popp 1960); $23=$ A. (A.) filiger (after HAMmer 1962). 

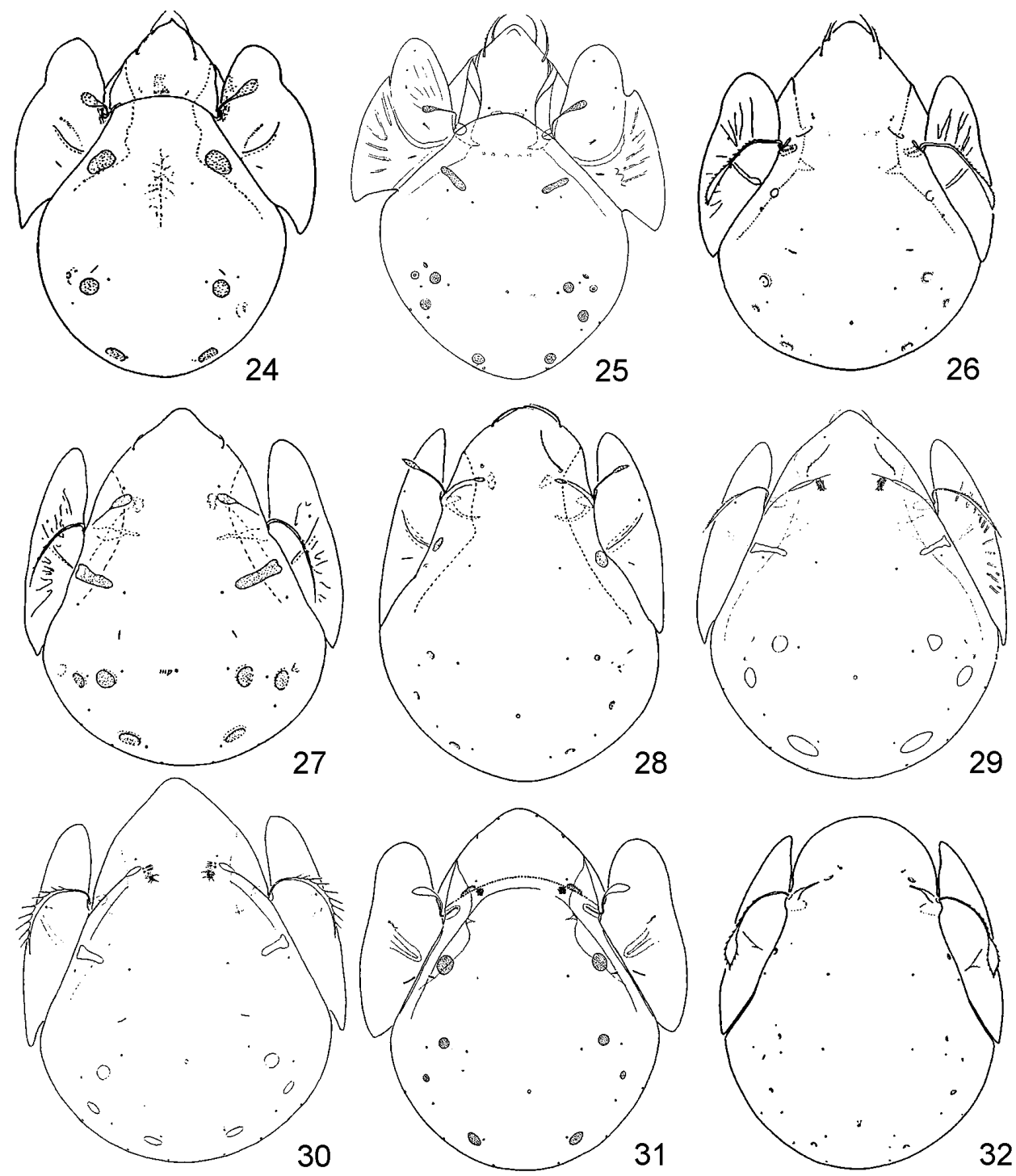

Figs 24-32. Allogalumna species: 24 A. = (A.) gedaii (after Mahunka 1995); $25=$ A. (A.) hydrophila (after HAMmer 1962); $26=$ A. (A.) incompleta (after MAHUNKA 1988).27 = A. (A.) insolita (after Mahunka 1996); $28=$ A. (A.) integer (after Mahunka 1992b); $29=$ A. (A.) leleupi (after Balogh 1962); $30=$ A. (A.) madagascarensis (after BALogh 1960b); $31=$ A. (A.) margaritifera (after Balogh 1960a); 32 = A. (A.) microporosa (after Mahunka 1978b). 
3 Legs monodactyle; median pore located in centrodorsal part of notogaster $(180-188 \times 114-123)$

A. (A.) monodactyla Ermilov et Anichkin, 2014 (Vietnam)

- $\quad$ Legs tridactyle; median pore located in posterior part of notogaster 4

4 Dorsosejugal furrow well developed, complete 5

- Dorsosejugal furrow medially undeveloped or absent 13

5 Notogaster with only two pairs of large porose areas $\left(A_{1}-A_{3}\right.$ fused) (264$290 \times 207-223$ )

A. (A.) confluens Balogh, 1960 (Congo)

- Three or four pairs of notogastral porose areas present 6

6 Three pairs of porose areas (usually $A_{3}$ reduced) $\quad 7$

- Four pairs of porose areas 9

7 Sensilli setiform, unilaterally ciliate; interlamellar setae well developed, long; lamellar setae represented by alveoli $(276 \times 196)$

A. (A.) alpha Pérez-Íñigo et Baggio, 1994 (Brazil)

- Sensilli with conspicuously dilated head; interlamellar setae minute; lamellar setae present

8 Sensilli with pointed head; rostrum rounded; porose areas small; lyrifissures im located laterad of $A_{1}(345 \times 219)$

$$
\text { A. (A.) exigua Popp, } 1960 \text { (Egypt) }
$$

- Sensilli with rounded head; rostrum pointed; porose areas large; lyrifissures im located anteriad of $A_{1}(449-505 \times 312-346)$

A. (A.) gedaii Mahunka, 1995 (Thailand)

9 Porose areas $A a$ very large, triangular or elongate, transversely oriented

- $\quad$ Porose areas $A a$ round or slightly oval

10 Porose areas $A a$ triangular, with conspicuously widened lateral and narrowed medial parts; sensilli with slightly dilated head; interlamellar setae long $(600-615 \times 496-530)$

A. (A.) dentirostrata Bayartogtokh et Akrami, 2014 (Iran)

- Porose areas $A a$ elongate, 2-3 times longer than broad; interlamellar setae represented by alveoli 
11 Porose areas $A a$ nearly 3 times longer than broad, narrowed medially; $A_{1}$ rounded; sensilli with well dilated head; lyrifissures im located anterolateral to $A_{1}(450)$

A. (A.) hydrophila Hammer, 1962 (Chile)

- $\quad$ Porose areas $A a$ nearly 2 times longer than broad; $A_{1}$ irregular; sensilli narrow lanceolate; lyrifissures im located anteromedial to $A_{1}(683-781 \times$ 526-622) A. (A.) antillensis (Mahunka, 1998) (St. Lucia, Antilles)

12 Interlamellar setae minute; lamellar setae developed; dorsosejugal furrow concave medially; porose areas small; lyrifissures im located anterolateral to $A_{1}$; notogaster without longitudinal lines (297-336 × 190-224)

A. (A.) pellucida Wallwork, 1965 (Chad)

- Interlamellar and lamellar setae represented by their alveoli; dorsosejugal furrow convex; porose areas large; lyrifissures im located anteromedial to $A_{1}$; notogaster with short longitudinal lines (345-377 $\left.\times 235-262\right)$ A. (A.) scripta (Balogh et Mahunka, 1966) (Congo)

13 Notogaster with five pairs of porose areas, $A a$ divided into two parts A. (A.) bipartita (Aoki et Hu, 1993) (China)

- Notogaster with three or four pairs of porose areas, Aa not divided 14

14 Notogaster with three pairs of porose areas $\quad 15$

- Notogaster with four pairs of porose areas 16

15 Sensilli setiform, barbed; notogastral porose areas elongate; lyrifissures im located anterolateral to $A_{1}$, very close to it (840)

A. (A.) filiger Hammer, 1962 (Chile and Panama)

- Sensilli clavate, smooth; notogastral porose areas round; lyrifissures im located anteromedial to $A_{1}$, rather far from it (360)

A. (A.) upoluensis Hammer, 1973 (Samoa)

16 Sensilli setiform, or lanceolate with slightly dilated head 17

- Sensilli clavate, or lanceolate with well developed head 27

17 Aa round or nearly oval $\quad 18$

- Aa triangular, with widened lateral and narrowed medial parts $\quad 24$

18 Interlamellar setae minute or represented by alveoli 19

- Interlamellar setae well developed 22

19 Median pore present $\quad 20$

- Median pore absent $\quad 21$ 
20 Sensilli with weakly developed head, smooth; $A a$ oval and very large; anal plates without longitudinal striae; lamellar setae developed (400410) A. (A.) novazealandica Hammer, 1968 (New Zealand)

- Sensilli setiform, slightly barbed; Aa round with normal size; anal plates striate; lamellar setae represented by alveoli (564-581 × 415)

A. (A.) asetosa Ermilov et Kalúz, 2014 (India)

$21 A a$ small, slightly larger than others; genital and anal plates with some fine longitudinal striae $(542-598 \times 403-445)$

A. (A.) costata Mahunka, 1996 (Madagascar)

- Aa large, distinctly larger than others; genital plates with one long, longitudinal stria; anal plates smooth $(448-464 \times 332-365)$

A. (A.) ampla Ermilov, Starý, Sandmann, Marian et Maraun, 2013

(Ecuador)

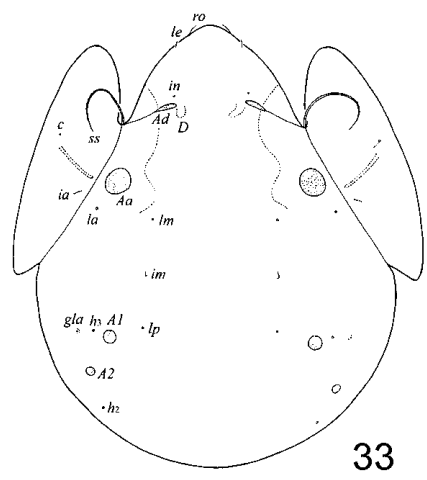

33

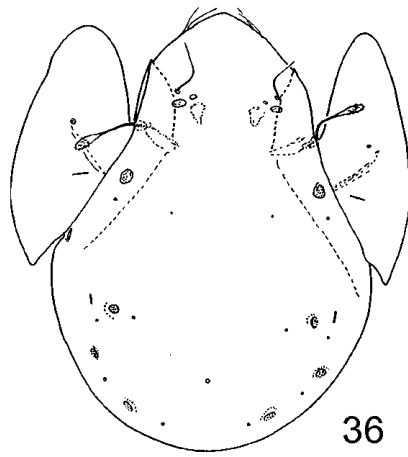

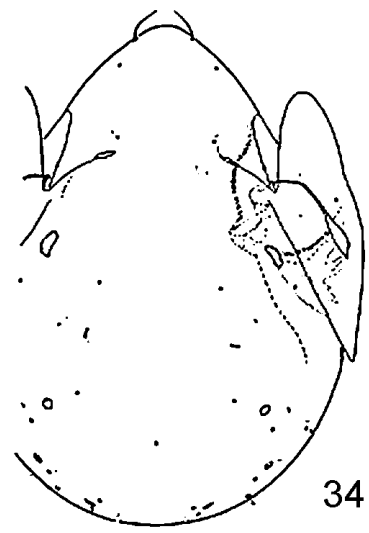

34

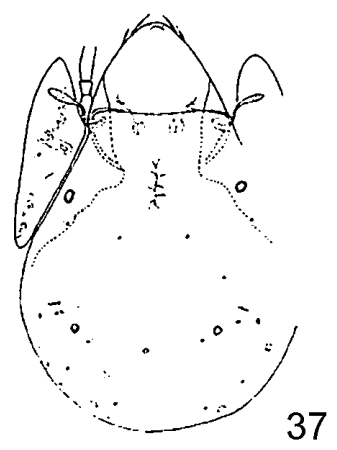

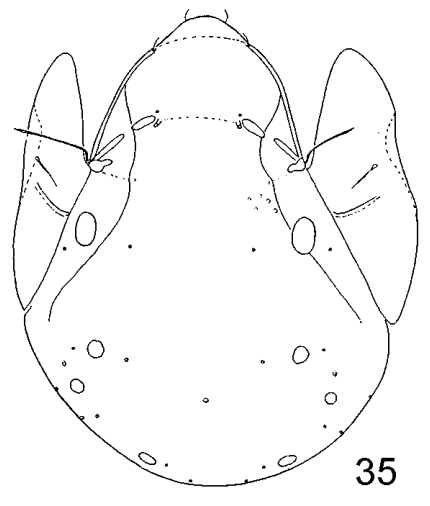

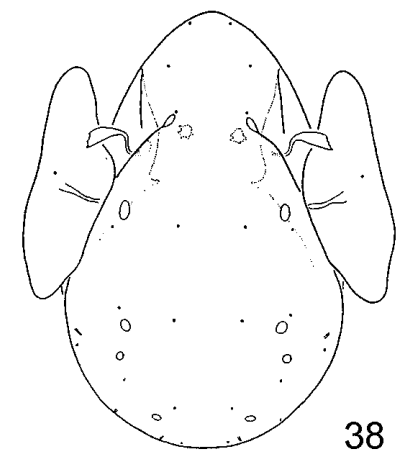

Figs 33-38. Allogalumna species: $33=$ A. (A.) ampla (after Ermilov et al. 2013); $34=$ A. (A.) multesima (after Grandjean 1957); $35=A$. (A.) novazealandica (after Hammer 1968); $36=A$. (A.) parva (after Mahunka 1992b); 37 = A. (A.) pellucida (after Wallwork 1965); $38=$ A. (A.) plowmanae (after BALOGH \& BALOGH 1983). 

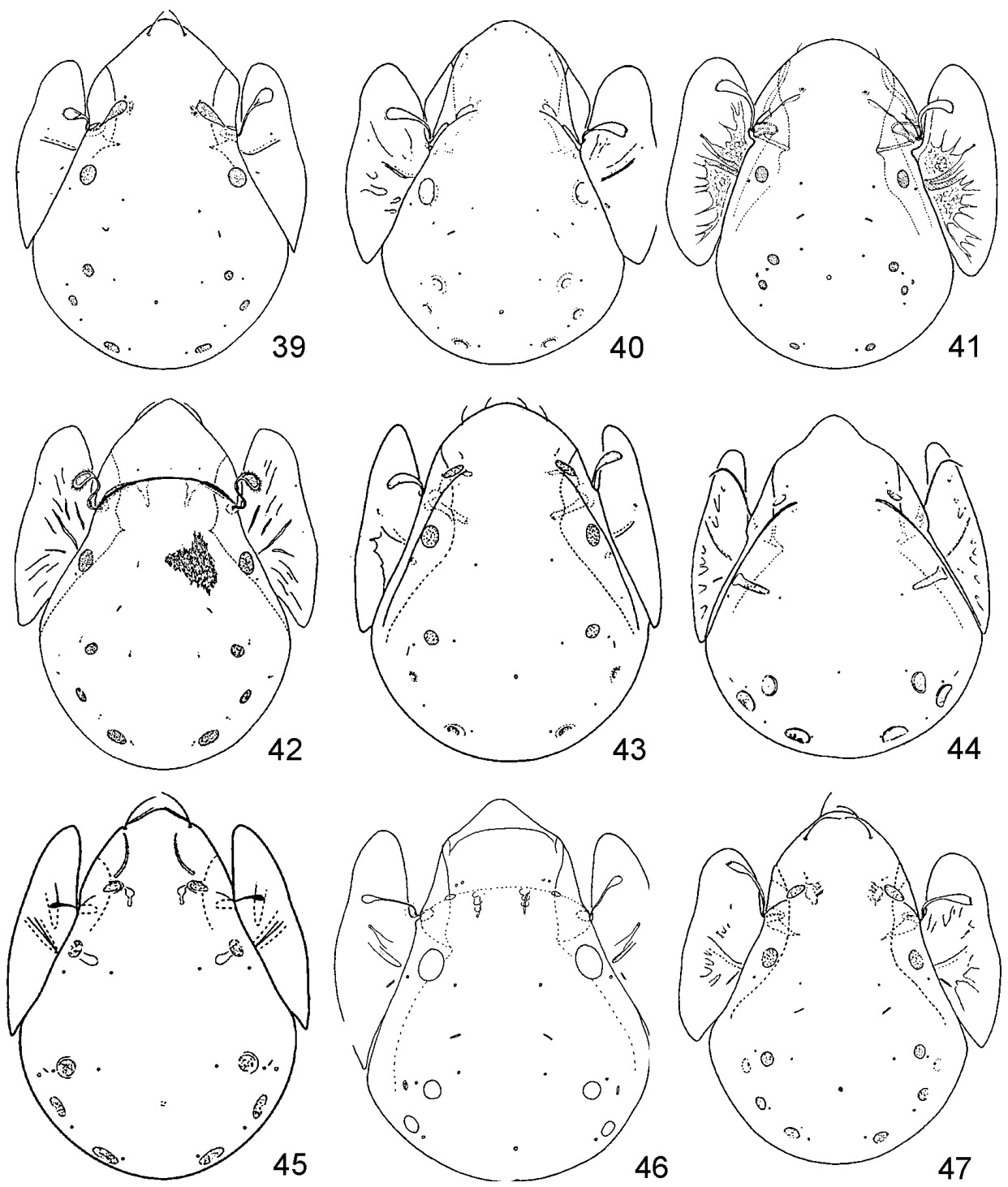

Figs 39-47. Allogalumna species: $39=$ A. (A.) pocsi (after Maнunka 1996); $40=$ A. (A.) quadrimaculata (after Mahunka 1988); $41=$ A. (A.) rotundiceps (after Aoki 1996); $42=$ A. (A.) scripta (after Balogh \& MahunKa 1966); $43=$ A. (A.) sinornata (after MahunKa 1992a); $44=A$. (A.) triangulata (after Mahunka 1978a); $45=A$. (A.) turkeyensis (after Grobler et al. 2004); $46=A$. (A.) upoluensis (after Hammer 1973); 47 A. (A.) vojnitsi (after MahunKa 1993). 

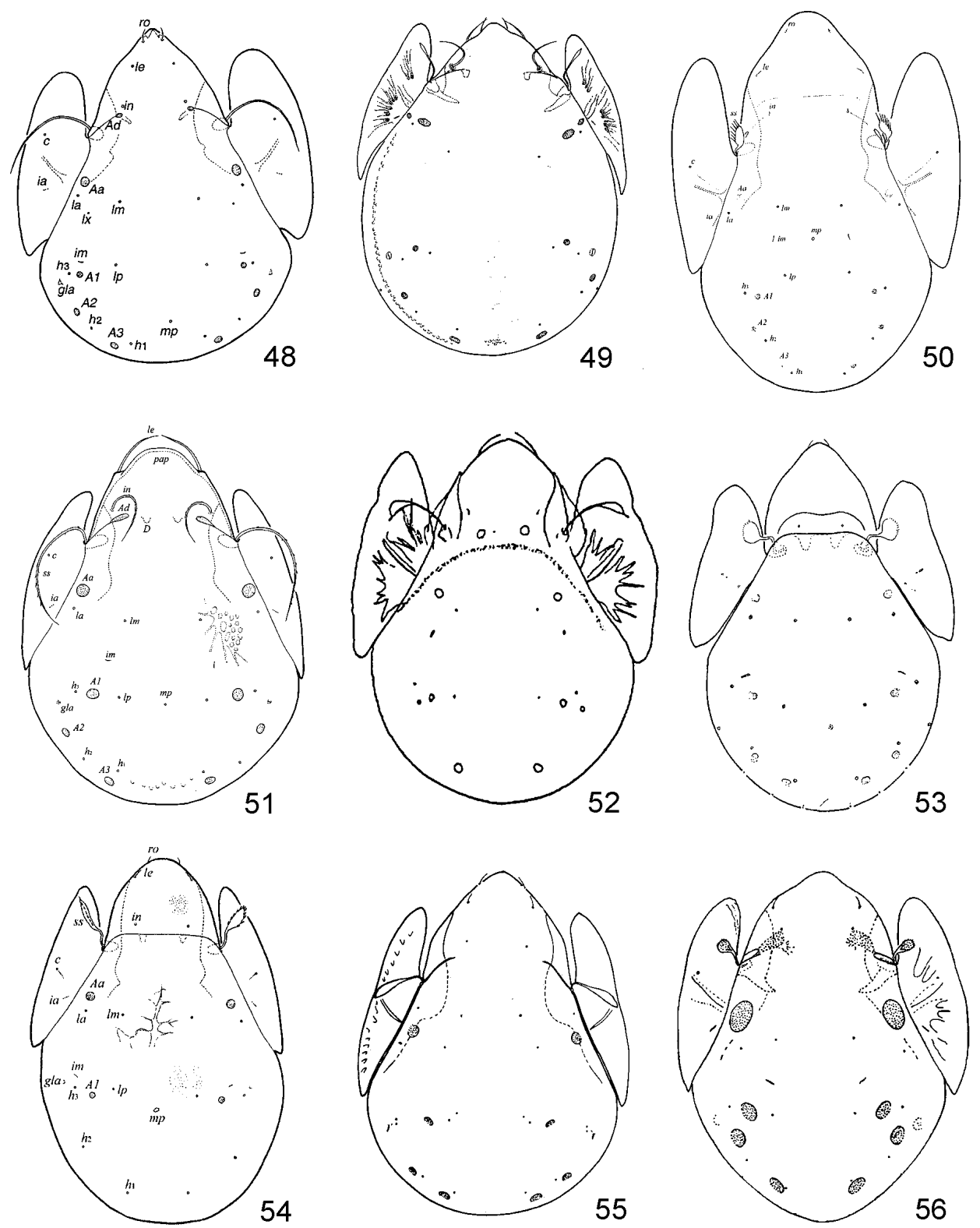

Figs 48-56. Allogalumna species: $48=A$. (A.) asetosa (after Ermilov \& Kalúz 2014); $49=A$. (A.) bipartita (after Aoki \& Hu 1993); $50=A$. (A.) monodactyla (after ERmilov \& ANichKin $2014 a) ; 51=$ A. (A.) paramachadoi (after ERmilov \& ANichkin 2014b); $52=$ A. (A.) curva ventralis (after Willmann 1931); $53=$ A. (G.) glubulifera (after Balogh \& Mahunka 1978); $54=A$. (G.) biporosa (after ERmilov \& AnichKin 2012); 55 = A. (A.) cubana (after BAlogh \& MahunKA $1979) ; 56=$ A. (A.) superporosa (after MAHunka 1996). 
22 Anterior part of prodorsum with large apophysis; sensilli setiform, ciliate; rostral setae densely ciliate (332-348 × 249-265)

A. (A.) paramachadoi Ermilov et Anichkin, 2012 (Vietnam)

- Anterior part of prodorsum without apophysis; sensilli with dilated head; rostral setae smooth

23 Sensilli with dilated head; lamellar setae ciliate; lyrifissures im located laterad of $A_{1}(440-540)$

A. (A.) integer (Berlese, 1904) (Southern central Europe)

- Sensilli with slightly dilated head; lamellar setae smooth; lyrifissures im located anteromediad of $A_{1}$ in middle part of notogaster $(453-489 \times 350-$ 380)

A. (A.) iranica sp. n. (Iran)

24 Interlamellar setae well developed $(398-404 \times 312-350)$

A. (A.) leleupi Balogh, 1962 (Tanzania)

- Interlamellar setae represented by alveoli

25 Sensilli with 9-10 long cilia; rostral setae represented by alveoli (301-354 $\times 261-274)$

A. (A.) madagascarensis (Balogh, 1960) (Madagascar)

- Sensilli with short cilia; rostral setae short

26 Sensilli with 2-3 cilia; lamellar setae developed, short; genital plates with one longitudinal stria $(394-428 \times 312-340)$

A. (A.) insolita Mahunka, 1996 (Madagascar)

- Sensilli densely ciliate; lamellar setae represented by alveoli; genital plates with several longitudinal striae $(446-458 \times 313-322)$

A. (A.) triangulata Mahunka, 1978 (Mauritius)

27 Interlamellar setae long

- Interlamellar setae minute or represented by alveoli

28 Interlamellar setae clearly thicker than lamellar and rostral setae, ciliate; porose areas $A_{1}-A_{3}$ little larger than $A a(369-421 \times 220-242)$

A. (A.) turkeyensis Grobler, Bayram et Çobanoglu, 2004 (Turkey)

- Interlamellar setae not thicker than lamellar and rostral setae, smooth; porose areas $A_{1}-A_{3}$ little smaller than $A a(420 \times 320)$

A. (A.) parva (Berlese, 1916) (Mediterranean)

29 Interlamellar setae minute, sometimes hardly visible 30

- Interlamellar setae represented by alveoli 37 
30 Lamellar setae minute, sometimes hardly visible or represented by alveoli

- Lamellar setae well developed, short or long 33

31 Rostral setae minute, hardly recognizable; sensillar head barbed; porose areas very small; lyrifissures im located posterolaterad of $A_{1}(206 \times 173-$ 185) A. (A.) microporosa Mahunka, 1978 (Northern Neotropical)

- $\quad$ Rostral setae long; sensillar head smooth; porose areas of medium size

32 Ventral side in epimeral region strongly chitinized; lyrifissures im located anteriad of $A_{1}(360 \times 255)$

A. (A.) curva ventralis Willmann, 1931 (tropical and Holarctic)

- Ventral side not chitinized; lyrifissures im located anteromediad of $A_{1}$ (215-245) A. (A.) multesima Grandjean, 1957 (Northern Neotropical)

33 Rostral setae long 34

- Rostral setae short, well visible $\quad 35$

34 Rostral setae barbed; sensilli very long, nearly 3 times longer than lamellar setae, directed backwards, distally pointed; dorsosejugal furrow absent; anterior margin of genital plates with 3 pairs of setae close to each other (277-307 × 198-218) A. (A.) incompleta Mahunka, 1988 (Borneo)

- Rostral setae smooth; sensilli nearly 1.5 times longer than lamellar setae, its head with 3-5 strong spines; dorsosejugal furrow medially undeveloped; anterior margin of genital plates with only one pair of setae, the others set behind it longitudinally $(288-316 \times 218-235)$

A. (A.) vojnitsi Mahunka, 1993 (Tanzania)

35 Sensilli broadened distally, blunt at tip, with fine barbs on apical margin $(212-219 \times 155-160)$ A. (A.) rotundiceps Aoki, 1996 (Japan)

- Sensilli asymmetrically fusiform, pointed distally, with some small barbs on outer margin

36 Median pore located between porose areas $A_{1}$; all notogastral porose areas framed by an anelliform ring (243-264 × 193-202)

A. (A.) borhidii Balogh et Mahunka, 1979 (Neotropical)

- $\quad$ Median pore located between $A_{2}$; only porose areas $A_{2}$ and $A_{3}$ with ring $(281-306 \times 226-242)$

A. (A.) sinornata Mahunka, 1992 (Senegal) 
37 Lamellar setae minute, sometimes hardly visible or represented by alveoli

- Lamellar setae well developed, short $\quad 41$

38 Rostral setae represented by alveoli 39

- Rostral setae minute, sometimes hardly visible 40

39 Sensilli hatchet like, with a small hyaline band on its distal end; all porose areas surrounded by a ring, $A_{2}$ of medium size; dorsosejugal furrow medially undeveloped $(389-405 \times 275-300)$

$$
\text { A. (A.) quadrimaculata (Mahunka, 1988) (Borneo) }
$$

- Sensilli fusiform, pointed distally; porose areas without ring, $A_{2}$ very small; dorsosejugal furrow absent, indicated by minute granules $(273 \times$ 200)

A. (A.) margaritifera Balogh, 1960 (Congo)

40 Sensillar head dilated, smooth; median pore present; lyrifissures im located far anterior to $A_{1}(290 \times 212)$

A. (A.) dilatata Balogh et Balogh, 1983 (Australia)

- Sensillar head denticulate; median pore absent; lyrifissures im located posterolaterad of $A_{1}(261 \times 171)$

$$
\text { A. (A.) plowmanae Balogh et Balogh, } 1983 \text { (Australia) }
$$

41 Median pore present; dorsosejugal furrow absent $(252-296 \times 197-214)$

$$
\text { A. (A.) pocsi Mahunka, } 1996 \text { (Madagascar) }
$$

- Median pore absent; dorsosejugal furrow medially undeveloped

42 Porose areas very large, $A_{1}$ and $A_{2}$ located near to each other; sensilli short with rounded head; notogaster strongly narrowed posteriorly; anterior margin of genital plates with only one pair of setae, the others set behind it longitudinally $(372-390 \times 174-280)$

$$
\text { A. (A.) superporosa Mahunka, } 1996 \text { (Madagascar) }
$$

- $\quad$ Porose areas of normal size, $A_{1}$ and $A_{2}$ located far from each other; sensilli long with pointed head; notogaster rounded posteriorly; anterior margin of genital plates with 2-3 pairs of setae close to each other (328-336 $\times$ 243-251)

A. (A.) cubana Balogh et Mahunka, 1979 (Cuba)

Acknowledgement - This study was partly supported by the project "Fauna of oribatid mites of Iran" funded by Shiraz University. 


\section{REFERENCES}

Aкrami, M. A. (2007) Introduction of twelve species of brachypyline oribatid mites (Acari: Oribatida: Brachypylina), new record to the fauna of Iran. Journal of Agricultural Science and Technology 9: 77-86.

Akrami, M. A., Haddad Irani-Nejad, K. \& Mirzaie, M. (2011) A new species of the genus Psammogalumna Balogh (Oribatida: Galumnidae) from Iran. Systematic and Applied Acarology 16: 27-34. doi: 10.11158/saa.16.1.4

Аокі, J. (1996) Two new species of oribatid mites of the family Galumnidae from Okinawa Island. Edaphologia 56: 1-4.

AокI, J. \& Hu, S. H. (1993) Oribatid mites from tropical forests of Yunnan province in China II, Families Galumnidae and Galumnellidae. Zoological Science 10(5): 835-848.

Balogh, J. (1960a) Oribates (Acari) nouveaux d'Angola et du Congo Belge ( $2^{\text {ème }}$ série). Companhia de Diamantes de Angola, Lisboa 51: 15-40.

BAlogh, J. (1960b) Oribatides (Acai) nouveaux de Madagaskar ( $1^{\text {re }}$ série). Mémories de l'Institut Scientifique de Madagaskar, Série A 14: 7-37.

BALOGH, J. (1962) Mission zoologique de l'I.R.S.A.C. en Afrique orientale. (P. Basilewsky et N. Leleup, 1957). LXXV. Acari Oribates. Annales du Musée Royal de l'Afrique Centrale Zoologie 110: 90-131.

Balogh, J. \& Balogh, P. (1983) New oribatid mites from Australia (Acari: Oribatei). Acta Zoologica Academiae Scientiarum Hungaricae 29 (1-3): 81-105.

BAlOGH, J. \& MahunKa, S. (1966) The scientific results of the Hungarian soil zoological expedition to the Brazzaville-Congo 3. The oribatid mites (Acari) of Brazzaville-Congo. I. Acta Zoologica Academiae Scientiarum Hungaricae 12(1-2): 25-40.

Balogh, J. \& MahunKa, S. (1978) New data to the knowledge of the oribatid fauna of the Neogea (Acari) III. Acta Zoologica Academiae Scientiarum Hungaricae 24: 269-299.

Balogh, J. \& Mahunka, S. (1979) New data to the knowledge of the oribatid fauna of the Neogaea (Acari). IV. Acta Zoologica Academiae Scientiarum Hungaricae 25(1-2): 35-60.

Bayartogtoкh, B. \& Aкrami, M. A. (2014) The soil mite family Galumnidae of Iran (Acari: Oribatida). Journal of Natural History 48: 881-917. doi: 10.1080/00222933.2013.840397

Berlese, A. (1904) Acari nuovi. Manipulus III. Redia 2: 10-32.

Berlese, A. (1916) Centuria prima di Acari nuovi. Redia 12: 19-67.

Ermilov, S. G. \& Anichkin, A. E. (2012) Two new oribatid mite species with auricilate pteromorphs from southern Vietnam (Acari: Oribatida: Parakalummidae, Galumnidae). Opuscula Zoologica Budapest 43(2): 161-167.

Ermilov, S. G. \& Anichkin, A. E. (2014a) Two new species of oribatid mites of the family Galumnidae (Acari, Oribatida) from Vietnam. ZooKeys 382: 53-66. doi: 10.3897/zookeys.382.6831

Ermilov, S. G. \& Anichis, A. E. (2014b) Taxonomic study of oribatid mites (Acari, Oribatida) of Bi Dup-Nui Ba National Park (southern Vietnam). Zootaxa 3834(1): 1-86. doi: 10.11646/zootaxa.3834.1.1

Ermilov, S. G. \& Kalúz, S. (2014) New species of oribatid mites of the genera Allogalumna, Galumna and Heterogalumna from India. Spixiana 37(1): 73-80.

Ermilov, S. G., Alvarado-Rudíguez, O., Retana-Salazar, A. P. (2014) Two new species of Pergalumna (Acari, Oribatida, Galumnidae) from Costa Rica, including a key to all species of the genus from the Neotropical region. Zookeys 435: 7-23. doi: 10.3897/ zookeys.435.8213 
Ermilov, S. G., Starý, J., Sandmann, D., Marian, F. \& Maraun, M. (2013) New taxa and new records of oribatid mites of the family Galumnidae (Acari: Oribatida) from Ecuador. Zootaxa 3700: 259-270. doi: 10.11646/zootaxa.3700.2.4

Grandjean, F. (1957) Galumnidae sans carènes lamellaires (Acariens, Oribates) 2e série. Bulletin de la Société Zoologique de France 82(1): 57-71.

Grandjean, F. (1936) Les Oribates de Jean Frédéric Hermann et de son père. Annales de la Societe Entomologique de France 105: 27-110.

Grobler, L., Bayram, S. \& Çobanoglu, S. (2004) Two new species and new records of oribatid mites from Turkey. International Journal of Acarology 30(4): 351-358. doi: 10.1080/01647950408684405

Hammer, M. (1962) Investigations on the oribatid fauna of the Andes Mountains III. Chile. Det Kongelige Danske Videnskabernes Selskab Biologiske Skrifter 13(2): 1-96.

Hammer, M. (1968) Investigations on the oribatid fauna of New Zealand, part III. Det Kongelige Danske Videnskabernes Selskab Biologiske Skrifter 16 (2): 1-96.

Hammer, M. (1973) Oribatids from Tongatapu and Eua, the Tonga Islands, and from Upolu, Western Samoa. Det Kongelige Danske Videnskabernes Selskab Biologiske Skrifter 20(3): $1-70$.

MahunKA, S. (1978a) Neue und interessante Milben aus dem Genfer Museum XXXIV. A compendium of the oribatid (Acari) fauna of Mauritius, Reunion and the Seychelles Is. II. Revue suisse de Zoologie 85 (2): 307-340.

MahunKa, S. (1978b) Neue und interessante Milben aus dem Genfer Museum XXV. On some oribatids collected by Dr. P. Strinati in Guatemala (Acari: Oribatida). Acarologia 20(3): 133-144.

Manunka, S. (1988) New and interesting mites from the Geneva Museum LXI. Oribatids from Sabah (East Malaysia) III (Acari: Oribatida). Revue suisse de Zoologie 95(3): 817888.

MahunKA, S. (1992a) New and interesting mites from the Geneva Museum LXIII. A survey of the oribatid fauna of Senegal (Acari: Oribatida). Revue suisse de Zoologie 99 (3): 673-712.

Mahunka, S. (1992b) "Pelops" and "Oribates" species in the Berlese-collection (Acari). Acta Zoologica Academiae Scientiarum Hungaricae 38 (3-4): 213-260.

Mahunka, S. (1993) A new series of publication on new or little known oribatid taxa from Africa (Acari), I. Acta Zoologica Academiae Scientiarum Hungaricae 39 (1-4): 91-119.

MahunkA, S. (1995) New oribatids (Acari: Oribatida) from Thailand. Acta Zoologica Academiae Scientiarum Hungaricae 41 (2): 137-145.

MahunKA, S. (1996) Galumnatoid taxa (Acari: Oribatida) from Madagascar (Part 1). Acta Zoologica Academiae Scientiarum Hungaricae 42 (2): 163-181.

MahunKA, S. (1998) New data on oribatids (Acari: Oribatida) from St. Lucia (Antilles). Acarologica Genavensia LXXXIX). Revue suisse de Zoologie 105(4): 839-877.

Mahunka, S. \& Акrami, M. A. (2001) Galumnatid mites from Iran (Acari, Oribatida). Annales historico-naturales Musei nationalis hungarici 93: 231-237.

Norton, R. A. \& Behan-Pelletier, V. M. (2009) Chapter 15. Oribatida. Pp. 430-564. In: Krantz, G. W. \& Walter, D. E. (eds): A manual of acarology. Texas Tech University Press, Lubbock (TX).

Pérez-Íñigo, C. \& Baggio, D. (1994) Oribates édaphiques du Brésil (VIII). Oribates de l'état de São Paulo (Cinquieme partie). Acarologia 35(2): 181-198.

Popp, E. (1960) Neue oribatiden aus Aegypten (Acarina). Bulletin de la Société Entomologique d'Egypte 54: 203-221. 
Subías, L. S. (2014) Listado sistemático, sinonímico y biogeográfico de los ácaros oribátidos (Acariformes: Oribatida) del mundo (excepto fósiles). Available from: http://escalera. bio.ucm.es/usuarios/bba/cont/docs/RO_1.pdf. (accessed in February 2014). First version published in Graellsia (2004), 60 (número extraordinario): 3-305.

Wallwork, J. A. (1965) Some Oribatei (Acari: Cryptostigmata) from Tchad (2nd series). Revue de Zoologie et de Botanique Africaines 72 (1-2): 83-108.

Willmann, C. (1931) Oribatei (Acari), gesammelt von der deutschen limnologischen Sunda-Expedition. Archiv für Hydrobiologie (Suppl. 9) 2: 240-305.

Revised version received November 26, 2014, accepted March 30, 2015, published August 14,2015 